\title{
STRATEGI DAN MODEL OMNIBUS LAW DALAM PENATAAN REGULASI
}

\author{
Ayon Diniyanto1, Bambang Sri Hartono ${ }^{2}$, Heris Suhendar ${ }^{3}$ \\ Institut Agama Islam Negeri Pekalongan ${ }^{123}$ \\ Email: ayondiniyanto24@gmail.com ${ }^{1}$,Email: \\ bambang.sri.hartono@iainpekalongan.ac.id², Email: \\ heris.suhendar@iainpekalongan.ac.id ${ }^{3}$
}

\begin{abstract}
Formation of the Omnibus Law, There are at least two basic reasons for the name many overlapping regulations and many regulations that are allegedly hampering investment so that the establishment of the Omnibus Law is expected to be able to overcome these two problems. The purpose of writing the article is to explain Omnibus Law in the system in Indonesia, the strategy and model of Omnibus Law in structuring regulations in Indonesia, and the challenges of Omnibus Law in structuring regulations. This article can be categorized as a type of normative juridical research using a qualitative approach. The source of data in writing this article uses secondary data consisting of primary legal materials in the form of Omnibus Law, secondary legal materials in the form of journal articles, law books, magazines and so on, and tertiary legal materials in the form of legal dictionaries, legal encyclopedias and others. . The results of the study indicate that the regulatory structuring strategy through the Omnibus Law can be carried out by establishing the basic and legal politics of the Omnibus Law, absorbing aspirations, coordinating with the regions, acceleration, transparency and accountability. The regulatory arrangement model through the Omnibus Law can be done with the regulation formation model, namely IRR. Meanwhile, the challenges of the Omnibus Law in structuring regulations are in the form of current and future challenges. In the formation of the Omnibus Law, the community is expected to participate in conducting supervision.
\end{abstract}

Keywords: Omnibus Law, regulation, strategy, arrangement, model

\begin{abstract}
Abstrak
Pembentukan Omnibus Law saat ini setidaknya ada dua alasan mendasar yakni banyak regulasi yang tumpang tindih dan banyak regulasi yang disinyalir menghambat investasi, sehingga dengan dibentuknya Omnibus Law nantinya diharapkan dapat mengatasi kedua permasalahan tersebut. Tujuan penulisan artikel yaitu menjelaskan tentang strategi dan model Omnibus Law dalam penataan regulasi di Indonesia, dan tantangan Omnibus Law dalam penataan regulasi. Artikel ini dapat dikategorisasikan sebagai jenis penelitian yuridis normatif dengan menggunakan pendekatan kualitatif. Sumber data dalam penulisan artikel ini menggunakan data sekunder yang terdiri dari bahan hukum primer berupa Omnibus Law, bahan hukum sekunder berupa artikel jurnal, bukubuku hukum, majalah dan lain sebagainya, dan bahan hukum tersier berupa kamus hukum, ensiklopedi hukum dan lain-lain. Hasil penelitian menunjukkan
\end{abstract}


bahwa Strategi penataan regulasi melalui Omnibus Law dapat dilakukan dengan pembentukan dasar dan politik hukum Omnibus Law, penyerapan aspirasi, koordinasi dengan daerah, akselerasi, transparansi dan akuntabilitas. Model penataan regulasi melalui Omnibus Law dapat dilakukan dengan model pembentukan regulasi yaitu IRR. Sedangkan tantangan Omnibus Law dalam penataan regulasi berupa tantangan saat ini dan masa mendatang. Dalam pembentukan Omnibus Law masyarakat diharapkan turut serta dalam melakukan pengawasan.

Kata Kunci: Omnibus Law, regulasi, strategi, penataan, model

\section{PENDAHULUAN}

Pemerintah Indonesia dalam beberapa pekan terakhir ini telah gencar untuk membuat regulasi berupa undang-undang sapu jagad atau Omnibus Law. Omnibus Law merupakan hukum yang mengatur berbagai hal. Beberapa objek aturan dapat dijadikan satu dalam satu hukum atau regulasi yang disebut sebagai Omnibus Law (Busroh, 2017: 242). Keinginan pemerintah untuk membuat Omnibus Law dilatarbelakangi oleh berbagai persoalan terkait dengan regulasi. Banyaknya regulasi yang tumpang tindih serta dalam rangka memangkas regulasi yang menghambat investasi membuat Pemerintah secara tegas akan membentuk Omnibus Law (Rongiyati, 2019: 1-2).

Tujuan utama pemerintah membuat Omnibus Law paling tidak ada dua yaitu pertama, merampingkan aturan serta penataan regulasi dan kedua, mempermudah investasi. Penataan regulasi memang merupakan salah satu tujuan utama pemerintah dalam membentuk Omnibus Law. Hal tersebut dapat dilihat dari keluhan pemerintah terkait dengan regulasi yang masih tumpang tindih sehingga menghambat investasi. Artinya dalam melihat dua tujuan utama tersebut, penataan regulasi merupakan hal yang harus diwujudkan agar kemudahan investasi dapat mengikuti (B. N. Indonesia, 2019: 25). Kemudian ada prinsip yang perlu diketahui bahwa tujuan sutau regulasi dapat tercipta apabila ada penegakan hukum yang benar (Rahardjo, 2009: 24).

Namun keinginan pemerintah tersebut dalam kenyataannya tidak mengalami langkah yang mulus. Masih ada beberapa problem dan tantangan yang harus dihadapi oleh pemerintah dalam membentuk Omnibus Law. Problem yang dihadapi pemerintah saat ini dalam membentuk Omnibus Law paling tidak yaitu terdiri dari problem materil dan formil. Problem materil terkait dengan substansi atau materi muatan dari Omnibus Law. Problem formil yaitu menyangkut tentang prosedur pembentukan Omnibus Law (Asni, 2019: 35).

Selain menghadapi problem tersebut, pemerintah juga harus menanggapi respon dari masyarakat terkait dengan akan adanya Omnibus Law. Respon dari berbagai masyarakat terhadap adanya Omnibus Law 
bermacam-macam mulai dari yang setuju dampai dengan menolak adanya Omnibus Law. Mereka juga mempunyai alasan masing-masing mulai dari alasan substansi Omnibus Law sampai dengan mekanisme pembentukan Omnibus Law (Putri, 2020). Respon dari masyarakat yang beragam tersebut sesungguhnya merupakan tantangan nyata yang dihadapi oleh pembentuk Omnibus Law yaitu pemerintah dan Dewan Perwakilan Rakyat atau DPR.

Pemerintah dan DPR harus transparan dalam menghadapi respon dari masyarakat. Politik hukum atau good will dari Omnibus Law harus dikemukakan secara jelas kepada masyarakat. Jika memang benar tujuan utama dari dibentuknya Omnibus Law adalah dalam rangka penataan regulasi dan mempermudah investasi, maka Pemerintah dan DPR harus menjelaskan secara konkrit kepada masyarakat. Pemerintah dan DPR juga harus mengemukakan secara detail bagaimana Omnibus Law dapat menata regulasi dan memudahkan investasi. Banyak masyarakat awam yang belum mengetahui urgensi Omnibus Law terutama urgensi dalam menata regulasi. Hal tersebut dikarenakan pembentuk Omnibus Law belum melakukan sosialisasi secara masif terkait pentingnya Omnibus Law dalam penataan regulasi. Apabila kondisi tersebut tidak diselesaikan oleh pembentuk Omnibus Law, maka jangan heran jika masyarakat melakukan respon bahkan penolakan terhadap adanya Omnibus Law.

Penelitian ini untuk membantu pemerintah dalam menjelaskan terkait dengan urgensi Omnibus Law dalam penataan regulasi. Penelitian ini juga memberikan kontribusi dengan merumuskan strategi dan model yang tepat dalam penataan regulasi melalui Omnibus Law. Penulis terlebih dahulu menemukan problem dan tantangan Omnibus Law dalam penataan regulasi. Setelah menemukan problem dan tantangan, selanjutnya adalah memformulasikan strategi dan model yang tepat dalam penataan regulasi melalui Omnibus Law. Oleh karena itu rumusan masalah dalam penelitian ini yaitu (1) bagaimana problem dan tantangan Omnibus Law dalam penataan regulasi; dan (2) bagaimana strategi dan model yang tepat dalam penataan regulasi melalui Omnibus Law.

\section{METODE PENELITIAN}

Artikel ini termasuk dalam kategori jenis penelitian yuridis normatif atau doktrinal dengan tema harmonisasi dan sinkronisasi hukum. Pendekatan yang digunakan dalam penelitian ini ialah pendekatan kualitatif, pendekatan penelitian yang menekankan pada memotret fenomena yang dikaji dalam penelitian kemudian mendeskripsikan hasil penelitiandalam bentuk narasi (Hardani et al., 2020: 277-278). pendekatan kualitatif ini digunakan untuk mengkaji terkait dengan Omnibus Law dari perspektif penataan regulasi melalui harmonisasi hukum. Penelitian ini 
juga menguraikan problem, tantangan, solusi, dan model penataan regulasi melalui Omnibus Law.

Sumber data dalam penulisan artikel ini menggunakan data sekunder yang terdiri dari bahan hukum primer berupa Omnibus Law, bahan hukum sekunder berupa artikel jurnal, buku-buku hukum, majalah dan lain sebagainya, dan bahan hukum tersier berupa kamus hukum, ensiklopedi hukum dan lain-lain. Teknik penggalian data menggunakan studi kepustakaan. Adapun data-data yang diperoleh selanjutnya dilakukan analisis data dengan menggunakan teknik analisis data diskriptif kualitatif.

\section{PEMBAHASAN}

\section{Omnibus Law dalam Sistem Hukum Indonesia}

Seperti yang telah disinggung sebelumnya bahwa Omnibus Law merupakan regulasi besar yang mengatur bermacam-macam objek aturan. Macam-macam objek aturan tersebut dibuat menjadi satu dalam suatu regulasi. Itulah salah satu pengertian dari Omnibus Law (Busroh, 2017: 242). Regulasi seperti ini memang masih terdengar aneh dan sebelumnya dapat dikatakan belum terlalu populer di Indonesia. Omnibus Law di Indonesia dapat dikatakan sebagai sesuatu yang baru. Hal tersebut dapat dilihat dari adanya dasar hukum Omnibus Law yang menjadi tanda tanya. Banyak kalangan yang menilai bahwa Omnibus Law tidak mempunyai dasar hukum di Indonesia. Di Indonesia memang belum ada regulasi yang spesifik mengatur terkait dengan pembentukan regulasi yang berbenuk Omnibus Law (Online, 2020).

Dasar hukum pembentukan peraturan perundang-undangan di Indonesia saat ini berpedoman pada Undang-Undang tentang Pembentukan Peraturan Perundang-Undangan. Artinya saat ini Omnibus Law mengacu pada regulasi tersebut. Kemudian bagaimana kedudukan Omnibus Law dalam sistem hukum Indonesia. Kedudukan Omnibus Law dalam sistem hukum Indonesia dapat dikatakan legal, apabila pembentukan Omnibus Law sesuai dengan Undang-Undang tentang Pembentukan Peraturan Perundang-Undangan.

Pembentukan Omnibus Law terutama dari segi formil sama dengan pembentukan undang-undang yang lain. Hanya materi muatan dalam Omnibus Law lebih banya dibandingkan dengan materi muatan dalam undang-undang biasanya. Kondisi tersebut tentu tidak bertentangan dengan sistem hukum mengingat aturan formil sesuai dengan UndangUndang tentang Pembentukan Peraturan Perundang-Undangan. Adapun terkait dengan aturan materil, apabila bertentangan, maka materi muatan dalam Omnibus Law apabila telah diundangkan dapat dilakukan pengujian peraturan perundang-undangan ke Mahkamah Konstitusi. 
Penataan regulasi di Indonesia saat ini terjadi problem. Banyak regulasi yang masih tumpang tindih. Maksud dari penataan regulasi sesungguhnya adalah melakukan harmonisasi dan sinkronisasi peraturan perundang-undangan. Harmonisasi dan sinkronisasi peraturan perundang-undangan merupakan inti dari penataan regulasi. Tanpa adanya harmonisasi dan sinkronisasi peraturan perundang-undangan, sulit untuk mewujudkan penataan regulasi. Harmonisasi dan sinkronisasi peraturan perundang-undangan dapat dilakukan dengan menggunakan model atau dapat disebut model penataan regulasi. Model pentaan regulasi ini dilakukan dari akar. Artinya penataan regulasi dilakukan saat pembentukan peraturan perundang-undangan.

Ada banyak model penataan regulasi mulai dari (1) Reg Map atau Regulatory Mapping (Rodiyah, 2016: 244-246); (2) RIA atau Regulatory Impact Assesment (Rodiyah, 2016: 219-225); (3) ROCCIPI yang merupakan kepanjangan dari Rule, Oportunity, Comunication, Capacity, Interest, Process, and Ideology (Mulyono, 2015: 113-115); (4) IRR atau Integrative Reg Map. Model-model tersebut merupakan model yang dapat dilakukan untuk penataan regulasi. Model tersebut ternyata tidak sebatas pada harmonisasi dan sinkronisasi peraturan perundang-undangan, melainkan lebih dari itu. Model Reg Map merupakan model yang menekankan pada adanya harmonisasi dan sinkronisasi peraturan perundang-undangan. Adapun model IRR merupakan integrasi dari model Reg Map dengan model RIA Map (Rodiyah, 2016: 297-299; Rodiyah et al., 2018: 4).

\section{Problem Omnibus Law dalam Penataan Regulasi di Indonesia}

Seperti yang telah disinggung sebelumnya bahwa inisiasi Pemerintah untuk membentuk regulasi berupa Omnibus Law tidak lepas dari adanya problem dan tantangan yang harus dihadapi. Problem materil dan formil dari adanya Omnibus Law sesungguhnya dapat dikatakan sebagai sedikit problem yang muncul dipermukaan dan diliput oleh media. Masih banyak problem-problem lain yang membayangi Omnibus Law seperti masalah administrasi dan teknis. Problem tersebut dapat dikatakan berpotensi besar muncul mengingat Indonesia baru mencanangkan Omnibus Law. Begitu juga dengan tantangan dari adanya Omnibus Law. Respon dan penolakan dari masyarakat terhadap adanya Omnibus Law dapat dikatakan merupakan tantangan saat ini yang harus dihadapi oleh pembentuk Omnibus Law. Tetapi ada tantangan kedepan yang juga harus dihadapi dalam membentuk Omnibus Law. Perkembangan zaman yang begitu cepat dan dinamis merupakan tantangan kedepan yang nyata dan harus dihadapi. Jangan sampai Omnibus Law yang juga bertujuan untuk menjawab tantangan zaman, tetapi dalam realitasnya tidak mampu menyesuaikan perkembangan zaman yang begitu cepat. 
Lawrence M. Friedman telah jauh-jauh hari mengingatkan tentang sistem hukum atau regulasi yang baik. Ada setidaknya tiga pengaruh suatu sistem hukum dapat berjalan atau regulasi dapat ditegakan dengan benar. Tiga pengaruh tersebut meliputi substansi hukum, struktur hukum, dan budaya hukum. Substansi hukum berkaitan dengan materi muatan dalam dalam sebuah regulasi dalam hal ini Omnibus Law. Struktur hukum merupakan badan atau institusi yang melaksanakan Omnibus Law. Budaya hukum terkait dengan masyarakat yang berhubungan dan melaksanakan Omnibus Law (Friedman, 1975, pp. 14-16). Oleh karena itu Omnibus Law harus mampu mengakomodasi tiga pengaruh tersebut agar Omnibus Law mampu menjadi regulasi dan sistem hukum yang baik dan menyesuaikan dengan perkembangan zaman.

Problem nyata dari adanya Omnibus Law dalam penataan regulasi di Indonesia dapat dikatakan masih banyak. Memang Omnibus Law secara kasat mata dapat dikatakan mampu melakukan penataan regulasi dari aspek harmonisasi regulasi khususnya undang-undang (harmonisasi secara horisontal). Penulis juga sepakat bahwa Omnibus Law merupakan salah satu solusi untuk melakukan penataan regulasi. Hal tersebut karena Omnibus Law memangkas berbagai regulasi dan mengatur berbagai aspek yang berkaitan hanya dalam satu regulasi. Namun, tujuan Omnibus Law yang dapat melakukan penataan regulasi bukan bererti bebas dari problem. Penulis setidaknya menemukan problem dalam Omnibus Law yaitu problem materil dan problem formil dan ada empat problem materil yang berhasil penulis identifikasi.

Pertama, belum diketahui politik hukum Omnibus Law secara jelas dan detail. Selama ini masyarakat umum belum mengetahui sesungguhnya apa politik hukum pembentukan Omnibus Law selain penataan regulasi dan menarik investasi. Belum jelasnya politik hukum dari Omnibus Law jelas sekali merupakan suatu problem yang sangat besar. Politik hukum menurut Mahfud MD yaitu kebijakan hukum yang dikeluarkan oleh negara untuk mewujudkan tujuan negara (Mahfud, 2009: 1). Artinya Omnibus Law dibentuk harus dalam rangka mewujudkan tujuan negara seperti yang termuat dalam Pembukaan Undang-Undang Dasar Negara Republik Indonesia Tahun 1945. tujuan negara yang termuat dalam Pembukaan Undang-Undang Dasar 1945 seperti (1) melindungi segenap bangsa Indonesia dan seluruh tumpah darah Indonesia; (2) memajukan kesejahteraan umum; (3) mencerdaskan kehidupan bangsa; dan (4) ikut melaksanakan ketertiban dunia. Tanpa adanya kejelasan terlebih dahulu tentang politik hukum Omnibus Law maka penataan regulasi melalui pembentukan Omnibus Law hanya semu. Politik hukum yang belum jelas dari Omnibus Law akan memberikan kesulitan dalam sinkronisasi dan harmonisasi regulasi. 
Diketahui bahwa setiap kebijakan hukum negara dalam hal ini regulasi terutama undang-undang harus mempunyai politik hukum. Jika Omnibus Law belum mempunyai politik hukum yang jelas, maka potensi tumpang tindih atau disharmonisasi akan sangat besar. Bisa dalam dua regulasi saling bertentangan atau dalam dua regulasi mengatur hal yang hampir sama sehingga tumpang tindih. Misalnya pembentuk undangundang mengajukan Rancangan Undang-Undang atau RUU tentang Cipta Lapangan Kerja yang merupakan Omnibus Law dengan politik hukum memajukan kesejahteraan umum. Tetapi pada saat yang bersamaan pembentuk undang-undang mengajukan RUU tentang Perlindungan Tenaga Kerja Honorer dan Tenaga Kerja Lepas (Pramubakti), RUU tentang Pengawas Ketenagakerjaan dan RUU tentang Perubahan atas Undang-Undang Nomor 13 Tahun 2003 tentang Ketenagakerjaan.

Ada banyak RUU yang diajukan oleh pembentuk undang-undang. RUU tentang Cipta Lapangan Kerja (Omnibus Law) mengatur hal yang hampir sama dengan RUU tentang Perlindungan Tenaga Kerja Honorer dan Tenaga Kerja Lepas (Pramubakti), RUU tentang Pengawas Ketenagakerjaan dan RUU tentang Perubahan atas Undang-Undang Nomor 13 Tahun 2003 tentang Ketenagakerjaan. Padahal semua RUU tersebut dapat dijadikan dalam satu RUU tentang Cipta Lapangan Kerja (Omnibus Law) atau diubah menjadi RUU Cipta Lapangan Kerja dan Ketenagakerjaan.

RUU tersebut sesungguhnya hampir sama pengaturannya dengan Omnibus Law Cipta Lapangan Kerja yaitu tentang pekerjaan dan tenaga kerja. Politik hukum dari semua RUU tersebut juga dapat dikatakan sama yaitu memajukan kesejahteraan umum. Apabila semua RUU tersebut disetujui dan disahkan oleh pembentuk undang-undang, maka tujuan dari Omnibus Law dalam melakukan penataan regulasi akan sulit tercapai. Padahal Omnibus Law bertujuan memasukan semua hal di sektor tertentu dalam satu regulasi agar tidak terjadi disharmonisasi. Seharusnya semua yang terkait dengan lapangan kerja, pekerjaan, dan tenaga kerja diatur dalam satu regulasi (Omnibus Law) yang konsisten. Misalnya RUU tentang Cipta Lapangan Kerja dan Ketenagakerjaan, sehingga sangat linier dan sinkron.

Ketika membicarakan terkait dengan lapangan kerja sebagai media/objek, maka harus membicarakan juga tentang tenaga kerja sebagai subyek. Artinya pembentukan regulasi Cipta Lapangan Kerja harus bersama-sama dengan pembentukan regulasi tentang Ketenagakerjaan. Regulasi tersebut harus dalam satu regulasi (Omnibus Law). Sebagai contoh Omnibus Law tentang Cipta Lapangan Kerja dan Ketenagakerjaan. Omnibus Law tersebut lebih komprehensif dan konsisten karena mengatur tentang cipta lapangan kerja (media/objek) dan tenaga kerja (subjek). Oleh karena itu identifikasi politik hukum dari setiap RUU 
harus jelas agar mempermudah dalam membuat Omnibus Law yang komprehensif dan konsisten, sehingga mampu mewujudkan penataan regulasi khususnya secara materil.

Kedua, problem yang terjadi dalam Omnibus Law yaitu materi muatan Omnibus Law dianggap masih banyak yang merugikan masyarakat. Hal tersebut dianggap dirasakan oleh pekerja yang akan bersentuhan langsung dengan Omnibus Law khususnya Omnibus Law tentang Cipta Lapangan Kerja (Mukaromah, 2020). Anggapan masyarakat bahwa materi muatan Omnibus Law masih merugikan masyarakat dapat dikatakan masyarakat secara representatif kurang dilibatkan dalam pembentukan Omnibus Law.

Pelibatan masyarakat yang representatif dan penyerapan aspirasi masyarakat yang representatif tentu tidak akan merugikan masyarakat. Terlebih, Negara Indonesia merupakan negara demokrasi yang tentu harus memperhatikan aspirasi masyarakat secara menyeluruh atau representative (Diniyanto, 2018: 424-425, 2019: 165). Selain itu, Pemerintah dan Dewan Perwakilan Rakyat (DPR) sebagai pembentuk Omnibus Law merupakan pranata yang bertugas untuk memenuhi kebutuhan masyarakat dalam mengatur kehidupan bermasyarakat (Koentjaraningrat, 1983: 170). Oleh karena itu pelibatan masyarakat harus diserap agar pembentukan regulasi berupa Omnibus Law sesuai dengan kebutuhan masyarakat.

Pelibatan masyarakat dapat menjadikan keinginan masyarakat secara representatif dapat diakomodasi dalam pembentukan Omnibus Law. Kurangnya pelibatan atau partispasi masyarakat dalam pembentukan Omnibus Law jelas merupakan potensi problem yang akan datang kemudian. Omnibus Law yang baru disahkan dapat menjadi lumbung uji materi atau judicial review masyarakat ke Mahkamah Konstitusi. Masyarakat dapat secara aktif melakukan uji materi dengan alasan materi muatan Omnibus Law bertentangan dengan keinginan masyarakat yang terdapat dalam konstitusi (Martitah, 2016: 98-103).

Kondisi tersebut sebenarnya dalam aspek penataan regulasi kurang diharapkan. Hal tersebut dikarenakan semakin banyak materi muatan Omnibus Law yang di judicial review dan kemudian dikabulkan Mahkamah Konstitusi, maka semakin banyak materi muatan yang hilang dalam Omnibus Law. Keadaan tersebut jelas sekali merugikan dari aspek penataan regulasi. Penataan regulasi yang dikonstruksi melalui materi muatan dalam Omnibus Law sedikit-sedikit dapat hilang karena judicial review yang dikabulkan. Tetapi judicial review merupakan hak konstitusional warga negara Indonesia yang dilindungi oleh konstitusi. Artinya pembentuk Omnibus Law harus berhati-hati dalam merumuskan materi muatan Omnibus Law. Materi muatan yang dimasukan dalam Omnibus Law harus benar-benar sesuai dengan konstitusi dan juga 
keinginan masyarakat. Hal ini perlu dilakukan untuk meminimalisir dikabulkannya judical review, sehingga tidak merusak penataan regulasi melalui konstruksi materi muatan Omnibus Law.

Ketiga, problem materil yang ada dalam Omnibus Law yaitu belum ditemukannya win-win solution tentang pro dan kontra dalam materi muatan Omnibus Law. Masyarakat saat ini terpolarisasi antara pro dan kontra dengan materi muatan Omnibus Law. Masyarakat juga mengalami pro dan kontra dengan pemerintah terkait Omnibus Law. Hal ini harus segera diselesaikan khususnya oleh pembentuk Omnibus Law. Jangan sampai tidak ada penyelesaian pro dan kontra tersebut secara win-win solution (Batubara, 2020: 37).

Pro dan kontra terkait Omnibus Law yang berlarut-larut dikhawatirkan akan menyebabkan adanya perbedaan kekuasaan di masyarakat, yaitu masyarakat yang pro dan kontra. Masyarakat yang pro akan merasa mendapat kekuasaan yang kuat karena aspirasi mereka tentang Omnibus Law diakomodasi. Sebaliknya, masyarakat yang kontra akan merasa termarjinalkan. Perbedaan di masyarakat yang seperti ini akan dapat menyebabkan terjadinya konflik sosial. Hal tersebut sudah diungkapkan dalam tesis Ralf Dahrendorf tentang konflik sosial. Ralf Dahrendorf memberikan kesimpulan bahwa konflik sosial terjadi karena perbedaan kekuasaan di masyarakat (Dahrendorf, 1959: 165).

Oleh karena itu, pro dan kontra di masyarakat tentang Omnibus Law harus segera diselesaikan. Kemudian, pro dan kontra terhadap materi muatan Omnibus Law yang tidak dapat diselesaikan jelas sekali akan menghambat pembentukan Omnibus Law. Hambatan tersebut jelas akan berkaitan dengan waktu yang artinya semakin masalah tidak selesai maka Omnibus Law tidak akan dibentuk. Konsekuensi yang harus dihadapi, penataan regulasi juga akan mengulur waktu lebih lama. Jelas ini tidak diharapkan karena tujuan Omnibus Law salah satunya yaitu melakukan akselerasi penataan regulasi.

Keempat, problem materil terakhir yang berhasil penulis identifikasi dari adanya Omnibus Law yaitu sulit melakukan harmonisasi secara vertikal. Omnibus Law akan mengalami kesulitan dalam melakukan harmonisasi regulasi secara vertika khususnya terhadap Peraturan Daerah atau Perda. Omnibus Law yang mengatur sektor tertentu dalam satu regulasi akan menjadikan pemerintah daerah mengambil tindakan. Apakah pemerintah daerah harus menyesuaikan Omnibus Law yang dibuat pemerintah pusat dengan membuat Perda Omnibus Law? Hal ini jelas akan menambah beban pemerintah daerah. Karena yang menjadi pertanyaan adalah mampukah daerah menyesuaikan dengan membuat Perda Omnibus Law? Kondisi seperti ini jelas sekali merupakan problem. Format penyesuaian regulasi di daerah terhadap adanya Omnibus Law dapat dikatakan belum jelas. Tanpa adanya format penyesuaian yang jelas 
maka penataan regulasi melalui harmonisasi secara vertikan dapat dikatakan tidak akan berhasil. Harus ada format penyesuaian regulasi dibawah terhadap Omnibus Law.

Omnibus Law selain mempunyai problem materil juga mempunyai problem formil. Problem formil dalam Omnibus Law adalah terkait dengan mekanisme atau prosedur pembentukan dari Omnibus Law. Prosedur tersebut dalam kenyataannya ada yang menyebabkan problem dalam penataan regulasi. Ada setidaknya tiga problem formil dalam Omnibus Law yang berhasil penulis identifikasi. Pertama, dasar hukum pembentukan Omnibus Law sesunggunghnya masih belum ada secara lex specialis derogat legi generali. Dasar hukum pembentukan Omnibus Law secara spesifik belum ada. Pembentukan Omnibus Law masih menggunakan dasar hukum yang umum yaitu Undang-Undang tentang Pembentukan Peraturan Perundang-Undangan (Online, 2020).

Seharusnya dasar hukum pebentukan Omnibus Law harus berbeda dengan pembentukan peraturan perundang-undangan lainnya. Hal tersebut karena Omnibus Law merupakan jenis undang-undang yang komprehensif. Walaupun Omnibus Law masih sama dengan undangundang yang lain dalam penyebutan dan kedudukan. Pembentukan dasar hukum yang spesifik terhadap pembentukan Omnibus Law sangat penting untuk dilakukan. Hal tersebut selain dikarenakan Undang-Undang tentang Pembentukan Peraturan Perundang-Undangan tidak mengatur secara spesifik tentang pembentukan Omnibus Law.

Materi muatan dalam Undang-Undang tentang Pembentukan Peraturan Perundang-Undangan juga menjadi pertanyaan. Apakah Undang-Undang tentang Pembentukan Peraturan Perundang-Undangan relevan dengan pembentukan Omnibus Law? Pertanyaan ini penting sekali untuk dijawab. Jangan sampai dasar hukum pembentukan Omnibus Law tidak jelas dan tidak spesifik. Hal tersebut akan menjadi masalah dalam pembentukan Omnibus Law terutama untuk penataan regulasi. Tidak adanya dasar hukum yang spesifik mengatur pembentukan Omnibus Law dapat menyebabkan tidak ada indikator yang jelas dalam pembentukan Omnibus Law. Misalnya terkait dengan kriteria aspek/sektor apa saja yang dapat dijadikan Omnibus Law. Kemudian syarat atau alasan apa saja yang dibolehka untuk membentuk Omnibus Law dan lain sebagainya. Hal-hal tersebut harus jelas dan diatur dalam regulasi yang kuat yaitu dalam Undang-Undang tentang Pembentukan Peraturan Perundang-Undangan.

Tidak adanya indikator atau syarat pembentukan Omnibus Law akan berpotensi terjadinya disharmonisasi regulasi. Belum adanya indikator atau syarat pembentukan Omnibus Law membuat pembentuk undangundang akan subyektif dalam membentuk Omnibus Law. Aspek dan kriteria berpotensi tidak menjadi pertimbangan, sehingga materi muatan dapat saling disharmoni. Penataan regulasi melalui pembentukan 
Omnibus Law dapat menjadi berbalik. Seharusnya pembentuk undangundang sebelum membentuk Omnibus Law harus membentuk dasar hukum pembentukan Omnibus Law secara spesifik. Sayang saat pembentuk undang-undang melakukan perubahan tentang UndangUndang tentang Pembentukan Peraturan Perundang-Undangan tidak memasukan indikator atau kriteria pembentukan Omnibus Law ke dalam perubahan Undang-Undang tentang Pembentukan Peraturan PerundangUndangan.

\section{Tantangan Omnibus Law dalam Penataan Regulasi}

Omnibus Law selain mempunyai problem juga mempunyai tantangan. Ada banyak tantangan yang harus dihadapi dalam hal ini oleh pembentuk Omnibus Law. Secara umum setidaknya ada dua tantangan dalam Omnibus Law yaitu tantangan saat ini dan tantangan yang akan datang. Tantangan saat ini yang harus dihadapi pembentuk Omnibus Law berdasarkan identifikasi penulis ada tiga.

Pertama, respon dari masyarakat terhadap adanya Omnibus Law. Respon yang beragam dari masyarakat bahkan ada yang menolak terhadap Omnibus Law harus dan disikapi dengan tepat oleh pembentuk Omnibus Law. Salah menyikapi terhadap respon masyarakat dapat menyebabkan adanya konflik secara vertikal antara masyarakat dengan pembentuk Omnibus Law. Pembentuk Omnibus Law harus hati-hati dalam menyikapi pernyataan masyarakat tentang Omnibus Law. Jangan sampai pembentuk Omnibus Law memberikan sikap yang dapat membuat masyarakat berkonflik karena Omnibus Law. Konflik yang terjadi dalam masyarakat terkait dengan Omnibus Law jelas sekali akan menghambat pembentukan Omnibus Law. Konsekuensi yang terjadi penataan regulasi ikut menjadi korban.

Kedua, yaitu tentang transparansi dalam pembentukan Omnibus Law. Seperti yang telah disinggung sebelumnya bahwa politik hukum Omnibus Law harus benar-benar disampaikan kepada masyarakat. Pembentukan Omnibus Law harus transparan dari segi materi (materi muatan) dan dari segi formal (prosedur pembentukan). Pembentukan Omnibus Law yang tidak transparan dapat menyebabkan masyarakat curiga dan akhirnya melakukan protes agar pembentuk Omnibus Law dapat terbukan serta akuntabel. Kondisi sepert ini tidak sejalan dengan akselerasi penataan regulasi. Karena pembentukan Omnibus Law masih berkutat didalam halhal yang menjadi perdebatan.

Ketiga, yaitu sosialisasi yang masif dalam rangka menjelaskan kepada masyarakat umum tentang Omnibus Law. Salah satu penyebab ketidaksepahaman antara masyarakat dengan pembentuk Omnibus Law adalah kurangnya sosialisasi. Tanpa adanya sosialisasi dan penyamaan pemahaman tentang materi muatan Omnibus Law maka pro kontra di 
masyarakat tentang Omnibus Law akan tetap berjalan dengan kuat. Adanya sosialisasi secara masif dan menyeluruh setidaknya dapat meminimalisir perbedaan pemahaman tentang materi Omnibus Law. Semakin banyak persamaan pemahaman tentang materi Omnibus Law akan semakin kecil potensi pro kontra tentang materi Omnibus Law. Keadaan seperti ini akan mendorong pembentukan Omnibus Law semakin cepat. Akibatnya penataan regulasi melalui Omnibus Law juga akan cepat terealisasi

Tantangan selanjutnya yang ada dalam Omnibus Law yaitu tantangan yang akan datang. Dua tantangan kedepan yang harus dihadapi oleh Omnibus Law yaitu (1) perkembangan zaman yang begitu cepat dan dinamis; serta (2) pergantian rezim pemerintahan dan kekuasaan politik. Perkembangan zaman yang begitu cepat dan dinamis merupakan tantangan nyata kedepan bagi Omnibus Law. Kedepan Omnibus Law harus mengikuti perkembangan zaman. Aspek-aspek yang kedepan tidak dapat diduga, harus siap-siap beradaptasi. Adapun aspek-aspek yang dapat diprediksi harus segera bersiap-siap untuk menghadapinya. Aspek yang dapat diprediksi biasanya dipengaruhi oleh teknologi, komunikasi, dan informasi. Oleh karena itu Omnibus Law harus dinamis dan juga responsif dalam menghadapi perkembangan zaman yang tidak dapat diduga dan dapat diprediksi (Muhtada \& Diniyanto, 2018: 100). Omnibus Law yang tidak mampu mengikuti perkembangan zaman tidak akan berguna. Selain itu, dapat mengakibatkan tumpang tindih regulasi karena kedepan dengan semakin banyak inovasi-inovasi maka akan semakin banyak hal yang diatur.

Tantangan kedepan selanjutnya yaitu tentang pergantian rezim pemerintahan dan kekuasaan politik. Indonesia dalam konstitusi jelas menyatakan bahwa mekanisme peralihan kekuasaan dilakukan melalui adanya Pemilihan Umum sebagaimana tertuang dalam Undang-Undang Dasar Negara Republik Indonesia Tahun 1945 Pasal 22E. Momen ini dapat menjadi momen pergantian rezim pemerintah dan kekuasaan politik. Omnibus Law di Indonesia dapat dikatakan diciptaan oleh pemerintah yang sedang menjalankan kekuasaan saat ini. Kedepan tentu kekuasaan tersebut dapat beralih mengingat konstitusi hanya menyatakan bahwa kekuasaan eksekutif dalam hal ini Presiden dan Wakil Presiden hanya dapat dipilih dalam dua kali masa jabatan seperti termuat dalam UndangUndang Dasar Negara Republik Indonesia Tahun 1945 Pasal 7.

Pembatasan tersebut jelas menjadi tantangan kedepan bagi Omnibus Law mengingat Presiden merupakan pembentuk salah satu Omnibus Law. Jangan sampai setelah adanya pergantian Presiden, program Omnibus Law ikut berganti. Bahkan Omnibus Law yang sudah disahkan dan diundangkan diubah atau diganti dengan undang-undang biasa. Keadaan seperti ini tidak boleh terjadi. Komitmen dari pembentuk undang-undang 
saat ini dan kedepan harus sama terhadap Omnibus Law. Ketidakberlanjutan Omnibus Law karena pergantian pemerintah dapat menghambat dan menjadi masalah dalam penataan regulasi melalui Omnibus Law. Regulasi yang telah disederhanakan dan diharmonisasikan akan kembali ke semula menjadi tumpang tindih.

\section{Omnibus Law di Kanada: Studi Perbandingan}

Omnibus Law pada dasarnya pernah dibentuk di berbagai negara. Salah satu negara yang cukup berhasil membentuk Omnibus Law yaitu Kanada. Kanada mampu membentuk Omnibus Law tanpa membuat gaduh di parlemen dan bahkan mampu membuat malu oposisi pemerintah. Pembentukan Omnibus Law membuat pemerintah diringankan dari berbagai perdebatan dengan parlemen khususnya oposisi. Perdebatan tersebut kerap memakan waktu lama dan memperpanjang proses legislatif. Adanya Omnibus Law membuat oposisi yang ada di parlemen kerap tidak bisa melakukan perlawanan. Kondisi tersebut diuntungkan terutama oleh pemerintah minoritas di parlemen. Fakta di Kanada menyatakan bahwa walaupun pemerintah mempunyai dukungan minoritas di parlemen tetapi Omnibus Law dalam kenyataannya tetap lolos dan diundangkan (Massicotte, 2013: 15-16).

Fakta di Kanada yang menyatakan bahwa pembentukan Omnibus Law tidak gaduh dan bahkan mampu dimenangkan minoritas dalam proses legislasi, setidaknya membawa pesan bahwa pembentukan Omnibus Law dapat dilakukan secara tenang terutama di parlemen. Hal tersebut bukan berarti pembentukan Omnibus Law di Kanada tidak ada kendala. Pembentukan Omnibus Law di Kanada dalam kenyataannya juga terdapat kendala. Namun kendala tersebut merupakan hal yang wajar di dalam suatu proses legislasi (Dodek, 2017: 21-22).

Pembentukan Omnibus Law di Kanada juga terjadi polemik di masyarakat. Omnibus Law di Kanada pernah ada yang digugat oleh masyarakat yaitu Omnibus Law tentang Jobs, Growth and Longterm Prosperity Act. Masyarakat menggugat Omnibus Law tersebut karena dianggap tidak dilakukan penyerapan aspirasi secara representatif dalam proses pembentukan. Tetapi pada akhirnya ada solusi terhadap permasalahan tersebut. Solusi yang dilakukan di Kanada yaitu adanya melakukan pemecahan dari satu Omnibus Law kedalam beberapa Omnibus Law. Hal tersebut dilakukan agar parlemen dan masyarakat dapat secara luas dan detail untuk mengkaji Omnibus Law (Juwana et al., 2020: 2-28).

Pembentukan Omnibus Law di Kanada tersebut dapat menjadi salah satu contoh pembentukan Omnibus Law di Indonesia. Pembentukan Omnibus Law di Kanada dapat menjadi contoh terkait dengan minimnya kegaduhan terutama di parlemen dan adanya ruang aspirasi bagi masyarakat yang luas. Fakta di Kanada bahwa pemerintah yang 
menguasai kursi minoritas di parlemen dapat membuat Omnibus Law, harus dapat dicontoh. Artinya bahwa kekuasaan politik yang kecil tidak selamanya sulit membentuk regulasi seperti Omnibus Law. Kondisi tersebut diharapkan dapat menjadi pandangan bagi pembentuk regulasi di Indonesia. Kemudian terkait dengan pemecahan satu Omnibus Law kedalam beberapa Omnibus Law juga patut dicontoh. Kanada lebih mengutamakan penyerapan aspirasi masyarakat agar masyarakat dapat terlibat aktif dalam mengkaji Omnibus Law, sehingga minim kegaduhan atau pro dan kontra di masyarakat. Indonesia dapat meniru langkah Kanada tersebut agar Omnibus Law yang terlalu obesitas untuk dipecah. Hal tersebut agar memberikan ruang aspirasi yang luas bagi masyarakat. Karena aspirasi masyarakat lebih penting dari pembentukan Omnibus Law.

\section{Strategi dan Model dalam Penataan Regulasi melalui Omnibus Law}

Problem dan tantangan seperti yang dikemukakan sebelumnya harus ditangani secara tuntas. Perlu ada jalan keluar yang konkrit menghadapi problem dan tantangan Omnibus Law dalam penataan regulasi. Jalan keluar yang dimaksud berupa strategi dan model dalam penataan regulasi melalui Omnibus Law. Problem dan tantangan yang telah disebutkan sebelumnya harus menjadi referensi dalam menyusun strategi dan model penataan regulasi melalui Omnibus Law. Artinya, walaupun penataan regulasi melalui Omnibus Law mempunyai problem dan tantangan. Sesungguhnya penataan regulasi dapat dilakukan melalui Omnibus Law dengan menggunakan strategi dan model yang tepat. Tanpa adanya strategi dan model yang tepat, problem dan tantangan penataan regulasi melalui Omnibus Law sulit diselesaikan. Konsekuensinya penataan regulasi melalui Omnibus Law sulit terwujud.

\section{Strategi Penataan Regulasi melalui Omnibus Law}

Strategi yang tepat dalam penataan regulasi melalui Omnibus Law merupakan suatu hal yang wajib dilakukan. Tanpa adanya strategi, penataan regulasi melalui Omnibus Law tidak akan terencana dan sulit untuk diwujudkan. Peneliti telah merumuskan strategi yang tepat dalam penataan regulasi melalui Omnibus Law. Ada setidaknya enam strategi yang harus dilakukan secara runtut yaitu (1) membuat dasar hukum pembentukan Omnibus Law; (2) menentukan politik hukum Omnibus Law; (3) penyerapan aspirasi masyarakat secara responsif; (4) koordinasi dengan daerah tentang pembentukan Omnibus Law; (5) akselerasi pembentukan Omnibus Law; dan (6) transparansi dan akuntabilitas.

a. Membuat dasar hukum pembentukan Omnibus Law

Dasar hukum pembentukan Omnibus Law merupakan suatu kewajiban yang harus dibuat. Tanpa adanya regulasi yang mendasari pembentukan Omnibus Law, aspek legalitas pembentukan Omnibus Law dapat cacat secara hukum. Undang-Undang tentang Pembentukan 
Peraturan Perundang-Undangan memang dapat dikatakan sebagai payung hukum pembentukan Omnibus Law. Tapi regulasi tersebut masih bersifat umum, dan perlu ada Dasar hukum khusus yang menjadi payung hukum pembentukan Omnibus Law. Dasar hukum khusus tersebut perlu dibuat dalam rangka mengatur pembentukan Omnibus Law agar indikator dan kriteria-kriteria yang harus ada dalam Omnibus Law menjadi jelas. Tanpa adanya dasar hukum yang khusus, akan membuat pembentukan Omnibus Law tidak terbatas dan dapat tidak terkontrol. Penataan regulasi juga akan terhambat karena tidak ada kejelasan indikator atau kriteria apa saja yang harus ada dalam membentuk Omnibus Law dan tumpang tindih regulasi berpotensi akan semakin besar.

b. Menentukan politik hukum Omnibus Law

Strategi kedua setelah membuat dasar hukum pembentukan Omnibus Law yaitu menentukan politik hukum Omnibus Law. Politik hukum dalam setiap pembentukan regulasi sangat penting termasuk dalam pembentukan Omnibus Law. Jangan sampai pembentukan Omnibus Law tidak mempunyai politik hukum yang berarti tidak mempunyai arah tujuan. Politik hukum harus ditentukan sebelum membentuk Omnibus Law agar mempunyai arah tujuan, sehingga tidak terjadi tumpang tindih dengan regulasi yang lain. Penentuan politik hukum Omnibus Law dibatasi yaitu dengan tujuan negara. Artinya politik hukum Omnibus Law apapun tidak boleh keluar dari tujuan negara.

c. Penyerapan aspirasi masyarakat secara responsif

Langkah strategi selanjutnya setelah menentukan politik hukum adalah melakukan penyerapan aspirasi masyarakat secara responsif. Penyerapan seperti ini mempunyai maksud bahwa pembentuk Omnibus Law harus menyerap aspirasi sesuai dengan keinginan masyarakat. Penyerapan seperti itu harus dilakukan secara masif dan representatif agar mampu sesuai dengan keinginan seluruh masyarakat. Responsif yang dimaksud adalah hasil penyerapan aspirasi dari masyarakat kemudian harus ditindaklanjuti dengan permusuan materi muatan Omnibus Law yang sesuai keinginan masyarakat. Jangan ada inkonsistensi antara hasil penyerapan aspirasi dengan perumusan materi Omnibus Law. Adanya penyerapan aspirasi masyarakat secara responsif dapat meminimalisir terjadinya pro dan kontra terhadap materi muatan Omnibus Law. penyerapan aspirasi masyarakat secara responsif juga dapat memaksimalkan materi muatan Omnibus Law agar sesuai dengan Undang-Undang Dasar1945. Karena aspirasi masyarakat tentu tidak akan jauh dari Undang-Undang Dasar 1945. Kondisi seperti ini perlu terjadi agar masyarakat tidak mengajukan judicial review ke Mahkamah Konstitusi yang dapat 
berpotensi menghambat penataan regulasi karena banyak materi muatan yang dihilangkan akibat dikabulnya judicial review.

d. Koordinasi dengan daerah tentang pembentukan Omnibus Law

Strategi penting selanjutnya dalam penataan regulasi melalui Omnibus Law yaitu dengan melakukan koordinasi dengan daerah tentang pembentukan Omnibus Law. Adanya otonomi daerah tidak lantas membuat daerah akan tunduk dan patuh terhadap pemerintah pusat dalam membentuk regulasi. Daerah tentu akan lebih mengutamakan program daerah dan kepentingan masyarakat lokal daripada mengikuti program pemerintah pusat. Hal itu dapat dibuktikan dengan pernah dilakukannya pembatala hampi ribuan Perda oleh pemerintah pusat. Namun kenyataannya Mahkamah Konstitusi dalam Putusan Mahkamah Konstitusi Nomor 137/PUUXIII/2015 menganulir kekuasaan pemerintah pusat untuk membatalkan Perda. Hal tersebut sejalan dengan adanya otonomi daerah yang mempekuat posisi daerah untuk mengelola daerah sendiri termasuk dalam membentuk regulasi yang sesuai dengan program prioritas daerah (Muhtada \& Diniyanto, 2017: 103-104).

Artinya pembentukan Omnibus Law tidak secara otomatis membuat daerah akan mengikuti dengan membentuk regulasi yang sesuai dengan tuntutan Omnibus Law. Oleh karena itu koordinasi antara pemerintah pusat dengan daerah harus dilakukan agar pembentukan Omnibus Law tidak tumpang tindih dengan program daerah yang berakibat tumpang tindih pula dengan regulasi di daerah. Penyamaan persepsi kondisi dan tujuan harus dilakukan antara pemerintah pusat dengan daerah. Hal ini agar daerah bersedia dan mampu mengikuti tuntutan Omnibus Law yang dibuat pemerintah pusat. Inilah yang dimaksud dengan harmonisasi regulasi secara vertikal.

e. Akselerasi pembentukan Omnibus Law

Pembentukan Omnibus Law merupakan regulasi yang harus cepat diselesaikan. Lamanya durasi pembentukan Omnibus Law akan berpengaruh terhadap penataan regulasi. Semakin lama pembentukan Omnibus Law, maka semakin lama penataan regulasi terwujud. Akselesarasi merupakan cara yang efektif agar pembentukan Omnibus Law cepat terwujud. Akselerasi pembentukan Omnibus Law dapat dilakukan dengan langkah-langkah strategi yang telah disebutkan sebelumnya. Selain itu juga diperlukan komunikasi politik antara Pemerinah dengan DPR. Dua lembaga negara ini berwenang membentuk Omnibus Law, namun dua lembaga ini merupakan lembaga politik sehingga pembentukan Omnibus Law tidak dapat diukur dengan batas waktu. Lembaga politik dalam memutus tentu mempunyai pertimbangan-pertimbangan politik yang tidak bisa dikalkulasikan dengan waktu. Oleh karena itu harus ada kesepahaman terlebih dahulu 
antara Pemerintah dan DPR tentang pentingnya Omnibus Law terutama dalam penataan regulasi. Ketika dua lembaga tersebut sudah samasama memahami pentingnya Omnibus Law dalam penataan regulasi, maka proses pembentukan Omnibus Law dapat berjalan dengan cepat tanpa menghilangkan kualitas pembentukan Omnibus Law.

f. Transparansi dan akuntabilitas

Strategi terakhir penataan regulasi melalui pembentukan Omnibus Law yaitu dengan transparansi dan akuntabilitas. Pembentuk Omnibus Law dalam proses pembentukan harus mengutamakan transparansi dan akuntabilitas. Semua materi muatan yang dibahas dalam pembentukan Omnibus Law harus transparan dan akuntabilitas. Transparan artinya materi muatan yang ada dalam RUU Omnibus Law harus terbuka. Begitu juga ketika pembahasan materi muatan Omnibus Law harus terbuka untuk umum. Adapun akuntabilitas yaitu materi muatan Omnibus Law yang dibahas dan disahkan harus dapat dipertanggungjawabkan oleh pembentuk Omnibus Law. Pertanggungjawaban tersebut dilakukan kepada publik sehingga publik dapat menilai. Penilaian publik dapat dilakukan dengan judicial review. Materi muatan Omnibus Law yang dibatalkan oleh Mahkamah Konstitusi ketika di judicial review menandakan bahwa materi muatan tersebut kurang akuntabilitas.

\section{Model Penataan Regulasi melalui Omnibus Law}

Strategi merupakan hal yang masih bersifat rencana, perlu ada tindak lanjut dengan suatu hal yang lebih mudah dilaksanakan. Model penataan regulasi melalui Omnibus Law merupakan hal yang implementatif sehingga mudah untuk dilaksanakan. Terkait dengan model penataan regulasi, maka tidak dapat dilepaskan dari model pembentukan regulasi. Terlebih Omnibus Law merupakan bagian dari pembentukan regulasi. Model pembentukan regulasi terdiri dari empat yaitu Reg Map, RIA, ROCCIPI, dan IRR. Reg Map atau Regulatory Mapping merupakan model pembentukan regulasi dengan memfokuskan pada pemetaan dan kajian regulasi. Ada enam prosedur yang digunakan dalam melakukan Reg Map yaitu perencanaan, pemetaan, kajian, laporan, diseminasi dan institusionalisasi. Model Reg Map lebih dikenal dengan penataan regulasi melalui sinkronisasi dan harmonisasi secara vertikal atau horizontal (Rodiyah, 2016: 244-246).

Model kedua yaitu RIA atau Regulatory Impact Assesment. Model pembentukan regulasi RIA lebih menekankan pada adanya terwujudnya iklim negara yang stabil dengan melalui sistem aturan yang berimbang. Ada tiga tujuan utama dari RIA yaitu (1) menilai efektifitas kebijakan yang ada; (2) memastikan pembentuk regulasi telah mengakomodir semua aspirasi; dan (3) identifikasi dampak 
setelah pembentukan regulasi. Adapun tahapan-tahapan RIA yaitu (1) perumusan masalah terhadap kebijakan yang akan dibuat; (2) identifikasi masalah; (3) identifikasi solusi; (4) identifikasi manfaat; (5) mengambil solusi terbaik; dan (6) strategi dan evaluasi. Model pembentukan regulasi melalui RIA lebih demokratis karena terlebih dahulu mengakomodir aspirasi dari berbagai stakeholder sebelum mengesahkan regulasi (Rodiyah, 2016: 219-225).

Model pembentukan regulasi yang ketiga yaitu model ROCCIPI. Model ini singkatan dari Rule, Oportunity, Comunication, Capacity, Interest, Process, and Ideology. Model pembentukan regulasi dengan ROCCIPI (Mulyono, 2015: 113-115). Model pembentukan regulasi yang terakhir yaitu model IRR singkatan dari Integrative Reg Map-RIA. Model IRR adalah atau gabungan dari model Reg Map dengan Model RIA. Model IRR selain akan melakukan sinkronisasi dan harmonisasi secara vertikal dan horisontal berdasarkan Reg Map. Model IRR juga akan mengutamakan aspek demokratis dengan mengakomodir semua aspirasi dalam membentuk regulasi sesuai dengan model RIA (Rodiyah, 2016: 297-299; Rodiyah et al., 2018: 4). Empat model tersebut perlu diidentifikasi untuk dirumuskan dan cocok dengan penataan regulasi melalui Omnibus Law.

Memperhatikan empat model tersebut, model IRR merupakan model yang tepat dalam penataan regulasi melalui Omnibus Law. Model IRR tepat untuk menjawab problem penataan regulasi melalui Omnibus Law. Apabila diidentifikasi secara mengerucut, sesungguhnya problem penataan regulasi melalui Omnibus Law ada dua. Pertama, problem harmonisasi secara vertikal khususnya. Kedua, problem terkait dengan akomodasi aspirasi yang sering menyebabkan pro dan kontra. Model pembentukan regulasi melalui IRR tepat sebagai solusi dalam menata regulasi melalui Omnibus Law. Artinya dalam pembentukan Omnibus Law harus menggunaan model IRR atau gabungan dari model Reg Map dengan RIA. Hal tersebut agar pembentukan Omnibus Law mempu melakukan penataan regulasi.

\section{SIMPULAN}

Penelitian ini dapat disimpulkan bahwa pembentukan Omnibus Law memang dapat dikatakan mampu menata regulasi. Namun apabila pembentukan Omnibus Law tidak dilakukan dengan tepat, penataan regulasi yang menjadi salah satu tujuan dapat tidak terwujud. Problem penataan regulasi melalui Omnibus Law terdiri dari problem materil dan problem formil. Problem materil seperti (1) politik hukum Omnibus Law belum diketahui secara detail; (2) materi muatan Omnibus Law dianggap masih ada yang merugikan masyarakat; (3) belum ada win-win solution; dan (4) sulit melakukan harmonisasi secara vertikal. Kemudian problem 
formil penataan regulasi melalui Omnibus Law meliputi (1) dasar hukum pembentukan Omnibus Law; (2) pembentukan Omnibus Law tergolong lamban; dan (3) pembentuk Omnibus Law terkesan kurang serius.

Tantangan penataan regulasi melalui Omnibus Law terdiri dari tantangan saat ini dan tantangan kedepan. Tantangan saat ini yaitu (1) respon masyarakat terhadap Omnibus Law; (2) transparansi pembentukan Omnibus Law; dan (3) sosialisasi terkait dengan pembentukan Omnibus Law. Tantangan kedepan yang harus dihadapi dalam penataan regulasi melalui Omnibus Law diantaranya (1) perkembangan zaman yang dinamis; dan (2) pergantian rezim pemerintahan dan kekuasaan politik.

Problem dan tantangan tersebut dapat diselesaikan dengan merumuskan strategi dan model yang tepat dalam penataa regulasi melalui Omnibus Law. Strategi yang tepat dan harus dilakukan yaitu dengan (1) membuat dasar hukum pembentukan Omnibus Law; (2) menentukan politik hukum Omnibus Law; (3) penyerapan aspirasi masyarakat secara responsif; (4) koordinasi dengan daerah terkait Omnibus Law (5) akselerasi pembentukan Omnibus Law; dan (6) transparansi dan aktabilitas. Selain menggunakan strategi tersebut juga diperlukan model penataan regulasi melalui Omnibus Law. Model yang dimaksud adalah model pembentukan Omnibus Law yang dapat melakukan penataan regulasi. Model penataan yang tepat yaitu menggunakan model IRR (Integrative Reg Map-RIA).

\section{DAFTAR PUSTAKA}

\section{Buku-buku}

Dahrendorf, R. (1959). Class and Class Conflict in Industrial Society. Standford University Press.

Friedman, L. M. (1975). The Legal System: A Social Science Perspective. Russell Sage Foundation.

Hardani, Auliya, N. H., Andriani, H., Fardani, R. A., Ustiawaty, J., Utami, E. F., Sukmana, D. J., \& Istiqomah, R. R. (2020). Metode Penelitian Kualitatif E Kuantitatif (Issue March). Penerbit Pustaka Ilmu.

Juwana, S., Gianova, G., \& Laidha, G. M. (2020). Sistem dan Praktik Omnibus Law Di Berbagai Negara dan Analisis RUU Cipta Kerja dari Perspektif Good Legislation Making.

Mahfud, M. (2009). Politik Hukum di Indonesia. Rajagrafindo Persada.

Martitah. (2016). Mahkamah Konstitusi: Dari Negative Legislature ke Positif Legislature? Konstitusi Press.

Muhtada, D., \& Diniyanto, A. (2018). Dasar-Dasar Ilmu Negara. BPFH Unnes. 
Mulyono, S. P. (2015). Model Pembentukan Peraturan Desa Berbasis Demokrasi Partisipatoris: Suatu Alternatif Pelaksanaan Undang-Undang Nomor 6 Tahun 2014 Tentang Desa. Abshor.

Rodiyah. (2016). Aspek Demokrasi dalam Pembentukan Peraturan Daerah. BPFH Unnes.

\section{Jurnal-jurnal}

Busroh, F. F. (2017). Konseptualisasi Omnibus Law Dalam Menyelesaikan Permasalahan Regulasi Pertanahan. Arena Hukum, 10(2), 227-250. https:/ / doi.org/10.21776/ub.arenahukum.2017.01002.4

Diniyanto, A. (2018). Tindak Pidana Pemilu dalam Perspektif Negara Demokrasi Indonesia. Seminar Nasional Hukum Universitas Negeri Semarang, 4(02), 422-429.

Diniyanto, A. (2019). Politik Hukum Regulasi Pemilihan Umum Di Indonesia: Problem Dan Tantangannya. Jurnal Legislasi Indonesia, 16(2), 160-172.

Dodek, A. M. (2017). Omnibus Bills: Constitutional Constraints and Legislative Liberations. Ottawa Law Review, 48(1), 1-42.

Massicotte, L. (2013). Omnibus Bills in Theory and Practice. Canadian Parliamentary Review, 36(1), 13-17.

Muhtada, D., \& Diniyanto, A. (2017). Harmonisasi Peraturan Daerah: Tantangan Dan Strategi Di Era Otonomi Daerah. Konferensi Nasional Hukum Tata Negara (KNHTN) Ke - 4 "Penataan Regulasi Di Indonesia."

Rodiyah, Utari, I. S., Muhtada, D., \& Waspiah. (2018). 2018 Village Bureaucracy Reform in Demoractic and Autonomy Era in Indonesia : Study of the Establishment of Laws and Regulations. South East Asia Journal of Contemporary Business, Economic and Law, 17(4), 1-6.

Rongiyati, S. (2019, December). Menata Regulasi Pemberdayaan UMKM Melalui Omnibus Law. Bidang Hukum Info Singkat: Kajian Singkat Terhadap Isu Aktual Dan Strategis, Vol. XI(23).

Sonata, D. L. (2014). Metode Penelitian Hukum Normatif dan Empiris: Karakteristik Khas dari Metode Meneliti Hukum. Fiat Justisia Jurnal Ilmu Hukum, 8(1), 15-35.

\section{Internet}

Asni, O. (2019). Pakar: Omnibus Law Tidak Mampu Selesaikan Persoalan Regulasi. Berita Satu. https://www.beritasatu.com/nasional/581562/pakar-omnibus-lawtidak-mampu-selesaikan-persoalan-regulasi 
Batubara, P. (2020). Pro-Kontra Omnibus Law Cipta Lapangan Kerja, DPRPemerintah Cari Solusi Bersama. Okezone.Com. https:/ / nasional.okezone.com/read/2020/01/24/337/2157530/prokontra-omnibus-law-cipta-lapangan-kerja-dpr-pemerintah-carisolusi-bersama

Indonesia, B. N. (2019). Omnibus Law: Harapan menarik investasi dan pembahasan yang sentralistik. BBC News Indonesia. https://www.bbc.com/indonesia/indonesia-50837794

Maharani, T. (2020). Jokowi Targetkan "Omnibus Law" Cipta Lapangan Kerja Selesai $100 \quad$ Hari. Kompas.Com. https:/ / nasional.kompas.com/read/2020/01/15/14424401/jokowitargetkan-omnibus-law-cipta-lapangan-kerja-selesai-dalam-100-hari

Online, H. (2020). RUU Omnibus Law Dinilai Tak Punya Pijakan Hukum. Hukumonline.Com.https:/ / www.hukumonline.com/berita/baca/lt5 e182c124b1bd/ruu-omnibus-law-dinilai-tak-punya-pijakan-hukum/

Putra, A. (2020). Partisipasi Publik dalam Pembentukan Omnibus Law. Tempo.Co. https://kolom.tempo.co/read/1298529/partisipasipublik-dalam-pembentukan-omnibus-law

Putri, B. U. (2020). 5 Alasan Serikat Pekerja Tolak RUU Omnibus Law. Tempo.Co. https://nasional.tempo.co/read/1295268/5-alasanserikat-pekerja-tolak-ruu-omnibus-law 
Ayon Diniyanto, dkk

Halaman ini sengaja dikosongkan 